\title{
Biomass production estimation of processing tomato using AquaCrop under different irrigation treatments
}

\author{
${ }^{1}$ Sándor Takács $-{ }^{2}$ Istvánné Rácz $-{ }^{2}$ Erzsébet Csengeri $-{ }^{3}$ Tibor Bíró \\ ${ }^{1}$ Institute of Horticulture, Faculty of Agriculture and Environmental Sciences, Szent István University, Páter K. út 1., H-2100 Gödöllő \\ ${ }^{2}$ Faculty of Agricultural Sciences and Economics, Szent István University, Szabadság út 1-3., H-5540 Szarvas \\ ${ }^{3}$ Institute of Hydraulic Engineering and Water Management, Faculty of Water Sciences, National University of Public Service, Bajcsy- \\ Zsilinszky utca 12-14. H-6500 Baja \\ takacs.sandor@mkk.szie.hu
}

\begin{abstract}
SUMMARY
The wiser usage of irrigation water is inevitable in the future. Irrigation has very high input cost; therefore, farmers must carry out irrigation with care. Also, the effect of irrigation on crops has a big role in decision making. Modeling provides a possibility to evaluate this effect. AquaCrop, as a crop production simulation model has great potential in this field. The accuracy of tomato biomass yield prediction of the model was tested in this research. For collecting the necessary data, a field experiment was conducted at Szarvas on processing tomato with different water supplies, such as 100\% (I100), 75\% (I75), 50\% (I50) of potential evapotranspiration and a control with basic water supply $(C)$. The relation of the simulation and actual biomass yields was evaluated during the season. Very good correlation was found between the modelled and the actually harvested data. The data for the control and I100 treatments showed higher correlation than the I75 and 150. The relationship for all of the data was moderately strong. Miscalculations occur mostly when the dry biomass yield reaches $7 \mathrm{tha}$. The accuracy of the model was evaluated with the use of mean absolute error (MAE) and root mean squared error (RMSE) values. The least error was found in the C treatment, which means 0.34 MAE and $0.45 \mathrm{tha}^{-1}$ RMSE. The simulation resulted in higher errors in the I75 and 150 treatments.
\end{abstract}

Keywords: crop simulation, modeling, validation, water supply

\section{INTRODUCTION}

An increasing amount of experience justify that successful and sustainable plant cultivation cannot be performed without planned irrigation. On many areas of the world, irrigation water is a limiting factor. In Hungary, where the irrigation from surface water is solved, then it is well supplied in general. Although, farmers must take into account the high energy cost that is essential for the water transportation and pumping. Learning the exact benefits of irrigation may contribute to use irrigation water and energy wisely. This knowledge can be aquired via modeling as well when the model is able to reveal the effect of irrigation on crop production. Besides, a good model can be a part of a farmer's decision support system, even if there are simpler methods to calculate irrigation water needs for processing tomato (Helyes and Varga, 1994). Moreover, deficit irrigation is a great concept to save water (Nemeskéri et al., 2015, 2018) or positively influence yield quality through raising soluble solids content (Patané and Cosentino, 2010). Processing tomato's respons to different level of water supply is well researched (Bőcs et al., 2011; Helyes et al., 2012, 2014; Pék et al., 2015) even if it is combined with mycorrhiza (Bakr et al., 2017; Le et al., 2016) or plant growth promoting rhizobacteria (Le et al., 2018).

We can follow tomato production looking at the data of Food and Agriculture Organization of United Nations (FAO). It shows, that the yield harvested in the world in the last two decades is increasing. In the European Union, the harvest area is in a decreasing tendency and the yield quantity was in the 15-20 million tonnes range between 1996 and 2016 (Food and Agriculture Organization, 2018). Reliable statistics for processing tomato only is accessable via World Processing Tomato Council (WPTC) data. According to the council, the production dropped from 38.7 Mt to 31.9 Mt in the last four years in the northern hemisphere, and from 11.2 Mt to $9.3 \mathrm{Mt}$ in the EU. Hungarian production was above 100,000 tonnes in these years and reached 120,000 tonnes in the 2018 season (World Processing Tomato Council, 2018).

AquaCrop, as a crop production simulation model, can describe the interactions between plant and soil (Raes, 2017; Steduto et al., 2012). A good model should be fast, simple as much as possible, but also fairly accurate and AquaCrop balance these expectations well (García-Vila and Fereres, 2012). Besides, training handbooks are also available for users (Raes, 2017; Raes and van Gaelen, 2017) The input data that are needed for an AquaCrop simulation is more or less easily collectible. However, to aquire a satisfying simulation at least the weather conditions, crop information (planting date, cultivar), field management (soil fertility, mulches, weed management), irrigation management (irrigation type, depths, dates), soil profile and groundwater information must be known (Raes, 2017). Very important to add these variables according to reality to get satisfying results in the end of the simulation. Testing AquaCrop to model crop parameters under diverse environments had been conducted in several plants, such as maize (Hsiao et al., 2009; Katerji et al., 2013), sunflower (Todorovic et al., 2009), wheat (Toumi et al., 2016) or even potato (Linker et al., 
2016; Montoya et al., 2016) and tomato (Katerji et al., 2013; Takács, et al., 2018; Takács et al., 2017). Also an interesting ability of the model, that it can estimate the stomatal closure percentage affected by soil water stress, which can be a good criteria for monitoring the state of plants (Takács et al., 2018). Stresses do not occur only under hot weather conditions, but also can be caused by cold temperature, which can be also simulated via AquaCrop modeling (Vanuytrecht et al., 2014).

\section{MATERIAL AND METHODS}

A field experiment was conducted at Szarvas, south-east Hungary on the experimental farm of Szent István University. The size of the experimental area was $\sim 0,5$ ha and it was divided into four, almost equal plots for the different water level treatments. Tomato seedlings (UG812 J F1 hybrid) were transplanted on $8^{\text {th }}$ May 2018 in single row style, where distance between rows was $140 \mathrm{~cm}$ and distance between plants was $20 \mathrm{~cm}$. The season ended on $14^{\text {th }}$ August. We used AcuaCrop v6.0 (Steduto et al., 2012) to determine the water demand of plants and to run the full season models for the four different water levels. The software calculates evapotranspiration according to the FAO Penman-Monteith method (Allen et al., 1998) that considers the development state of the plants as well as meteorological data. Three out of four plots were irrigated regularly with different proportions of the potential evapotranspiration (ET) computed with the software. One plot received $100 \%$ of ET (I100). There were two deficit irrigated plots. These were irrigated with $75 \%$ (I75) and $50 \%$ (I50) of ET. The control plot (C) was not regularly irrigated, except the plant recovery period after transplantation and the events of fertilization. This was necessary to reach a starting state with plants in good condition and to wash down fertilizer granulates off leaves, to avoid scorching. Sprinkler irrigation was performed with a precision centre pivot system equipped with individual sprinkler control variable rate irrigation (VRI iS), two times per week. The shapes of these plots and different irrigation rates were planned with Valley VRI 8.55 software in the beginning of the season. So, the whole experiment was placed under one sprinkler irrigation machine. The uniformity of the machine and the transition between zones had been evaluated (Takács et al., 2018). Irrigation was cut-off 25 days before harvest. The experiment was placed on clayloam soil. Meteorological data (such as temperature, relative humidity, wind speed, precipitation) were recorded by a meteorological station installed nearby the field. We collected biomass samples six times during the season. Firstly, the seedlings were measured at the time of transplantation on the first day. Further biomass samples were collected on the $28^{\text {th }}, 44^{\text {th }}, 64^{\text {th }}$ and $77^{\text {th }}$ day after transplanting. The final sample was collected at the time of harvest on $98^{\text {th }}$ day after transplanting. We cut out four plants randomly from every treatment at every occasion.
These plants were taken to the laboratory of Szent István Egyetem, Tessedik campus and were put into the drying cabinet to $105{ }^{\circ} \mathrm{C}$ for one day. After the $3^{\text {rd }}$ sampling date we put the plants and fruits for two days into the drying cabinet, instead of one day for reching constant weight. At harvest we measured 10 plants per treatment. Statistical tests were performed in R x64 3.5.1 (R Core Team, 2018). Pearson's correlation tests were used to see connection between modelled and the actual dry biomass production. Mean absolute error (MAE) and root mean squared error (RMSE) were used for the model evaluation.

The climate file was created from local meteorological data last from $1^{\text {st }}$ January 2017 to $14^{\text {th }}$ August 2018. The in-bulit Tomato crop file was used with several modifications of calendar dates and crop canopy cover. For the soil profile, samples were analyzed taken from different depths of the experimental field. Non-limited soil fertility and good weed management were set for the modelling. Groundwater table were set in $2 \mathrm{~m}$ depth.

\section{RESULTS AND DISCUSSION}

\section{Meteorology and irrigation}

The length of the season was 98 days. The mean temperature of the season was $22.3{ }^{\circ} \mathrm{C}$. The mean relative humidity was $69 \%$ and the total precipitation was $126.9 \mathrm{~mm}$ (Figure 1). Between the date of the last irrigation $\left(20^{\text {th }}\right.$ July) and harvest $\left(14^{\text {th }}\right.$ August) 35.8 $\mathrm{mm}$ rainfall was measured.

We irrigated the control with $43.6 \mathrm{~mm}$ water. This amount was distributed in the recovery period after transplanting and at the times of fertilization events, so it received $170.5 \mathrm{~mm}$ water in total. The total water amounts in the irrigated treatments were 340.4; 296.3 and 257.8 under the I100, I75 and I50 irrigation treatments, respectively (Figure 1).

\section{Biomass yields}

One way to interpret the modelled and the actual biomass dry yield data is to visualaze them on line charts. The more similar the lines, the better the results of the modeling. On Figure 2 the lines of the control (A) and the I50 (B) treatment are shown. In the case of control, the two lines are going together, following the same pattern. When the modelled line (dashed) is above the line representing the actual yield (solid), then the model is overestimating, and when it is below that, then the model is underestimating. According to the samples the actual yield reaches the maximum by the end of July in the $C$, while the modelled biomass yield is growing continously, so the modelled biomass is above the actual with $0.176 \mathrm{t} \mathrm{ha}^{-1}$ dry biomass yield by the time of harvest, which is a little more than $3 \%$ difference. Considering the MAE and RMSE for the control, this model has the least error values, which are 0.34 and $0.45 \mathrm{t} \mathrm{ha}^{-1}$, respectively. 


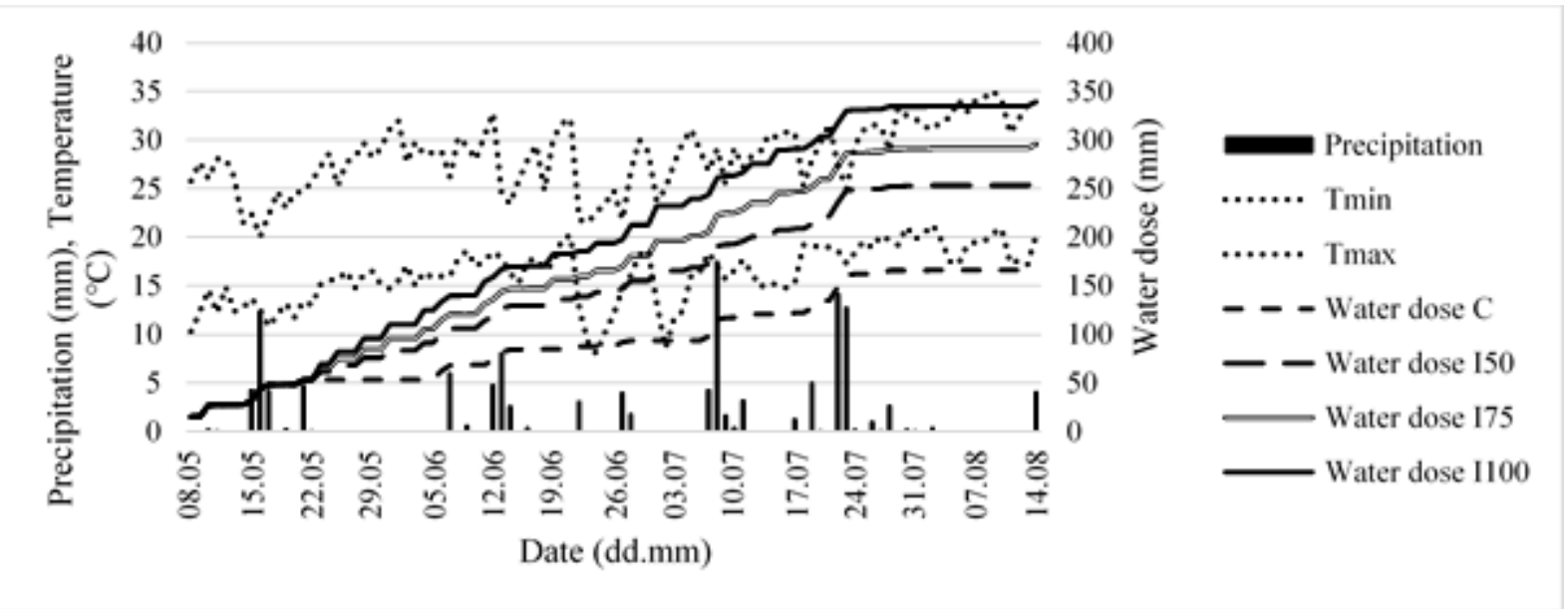

Figure 2: Relation of the actual and modelled biomass yield of the control (A) and the I50 (B) treatment in respect to sampling dates

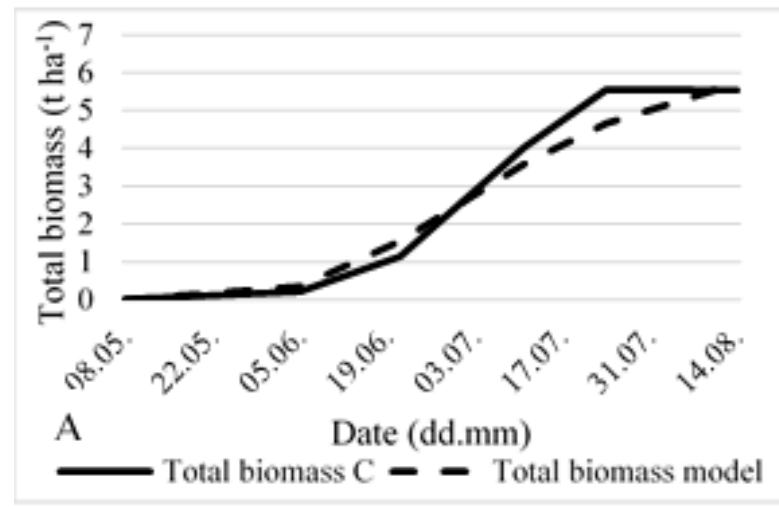

In the I50 treatment the modelled line is below the measured biomass line almost until the end of the season. However, between the last two sampling the two lines switch places and by the time of harvest overestimation occurs in this treatment as well. The extent of overestimation is $1.59 \mathrm{t} \mathrm{ha}^{-1}$, which means $22.9 \%$ difference. The data of the actual biomass shows that biomass is reduced for the last sampling. In the case of the I50 treatment the accuracy of the model was $1.15 \mathrm{tha}^{-1} \mathrm{MAE}$ and $1.45 \mathrm{tha}^{-1} \mathrm{RMSE}$.

The running of the lines in the 175 treatment is very similar to the I50 line chart. The underestimation of the model is present until the end of the season, where the modelled biomass yield rises above the measured yield. The overestimation is less than in the I50 treatment, $1.52 \mathrm{t} \mathrm{ha}^{-1}$ biomass yield. The actually measured biomass $84.3 \%$ of the modelled yield. The biomass yield reduction for the last sampling date compared to the $5^{\text {th }}$ date is observable in the 175 treatment too. It is shown on Figure 3. The largest errors occurred in the $\mathrm{I} 75$ model with $1.51 \mathrm{t} \mathrm{ha}^{-1}$ MAE and $2.09 \mathrm{t} \mathrm{ha}^{-1} \mathrm{RMSE}$. The modelled line fits excellent with the actual biomass yield line in the I100 treatment. A little amount of overestimation during the

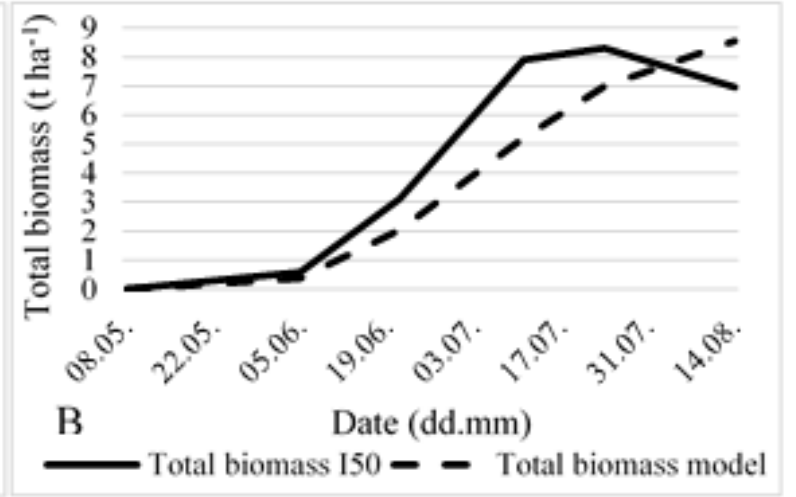

season disappears for the harvest date and the model underestimates with $0.09 \mathrm{t} \mathrm{ha}^{-1}$ dry biomass yield, which means less than $1 \%$ difference only. Despite, the least errors were found in the $\mathrm{C}$ model and not in the I100 model. However, the errors in the I100 were not too high either, $0.69 \mathrm{t} \mathrm{ha}^{-1}$ MAE and $0.95 \mathrm{t} \mathrm{ha}^{-1}$ RMSE, respectively.

The Pearson's correlation test revealed very strong correlation in the cases of the control and the I100 treatment, on $\mathrm{p}<0.001$ level (Figure 4). Slightly weaker correlation appears in the I50 and $\mathrm{I75}$ treatments, with p-values $<0.01$ and 0.014 , respectively. The main reason for that can be the bigger midseason inaccuracy, which can be seen on Figure $2 B$ and Figure $3 A$. Besides, the high miscalculations in the final yields might take a great role as well. 
Figure 3: Relation of the actual and modelled biomass yield of the I75 (A) and I100 (B) treatments in respect to sampling dates
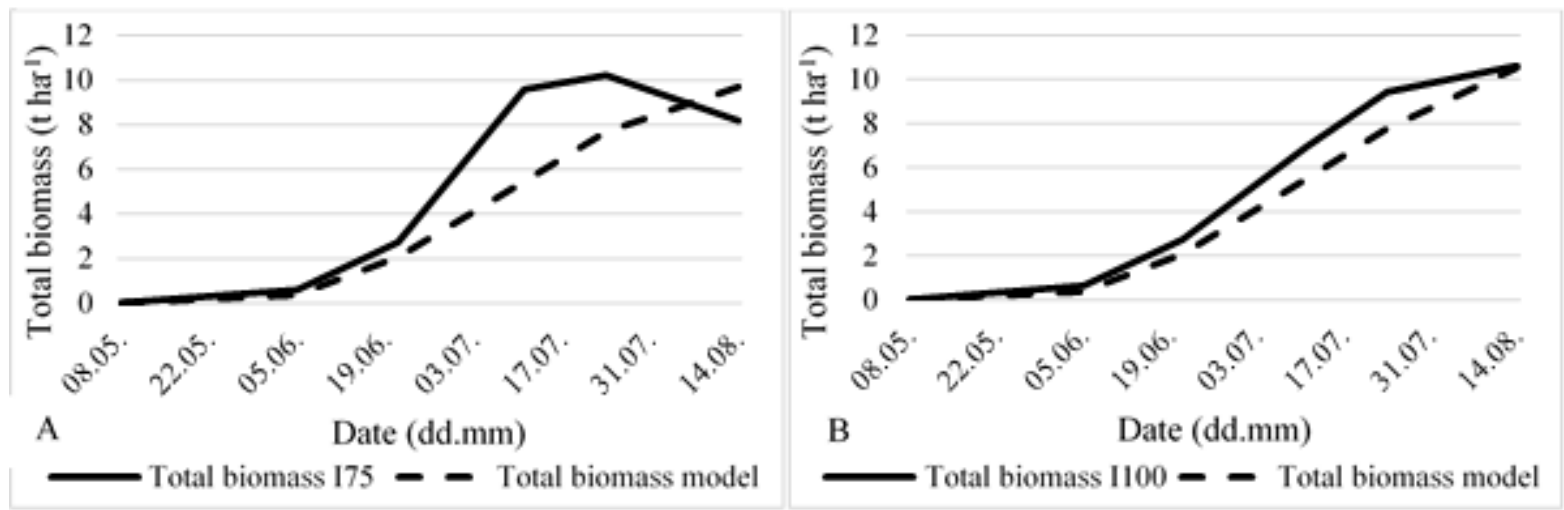

Figure 4: The modelled dry biomass yields in relation to the actual dry biomass yields in the four different treatments. (n=6)

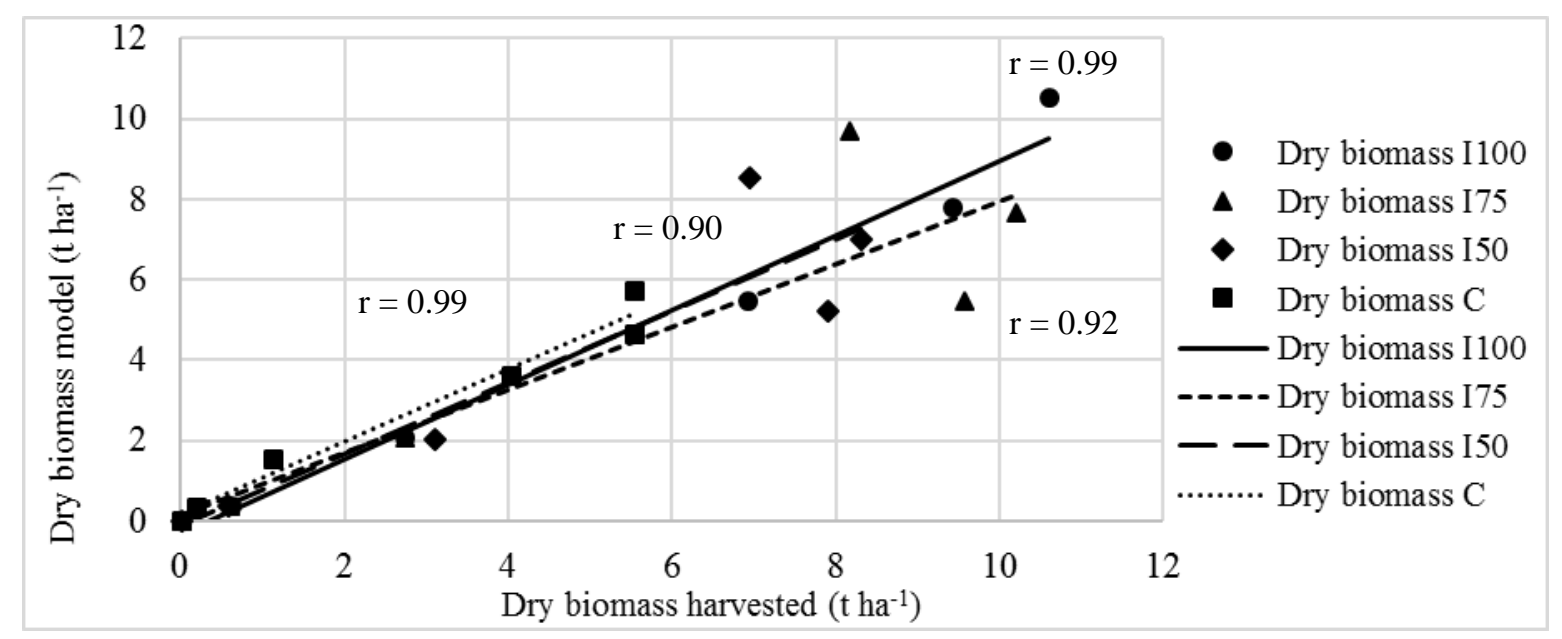

When we examined every sample point in one correlation test, they showed strong correlation. However, Figure 5 points out how scattered the points are in the upper region of the scatterplot, around and above $7 \mathrm{t} \mathrm{ha}^{-1}$ on the $\mathrm{x}$ axis. This means, that the higher the yields the higher the miscalculation by the model gets.

Figure 5: The connection between modelled and actual dry biomass yields. $(\mathbf{n}=\mathbf{2 4})$

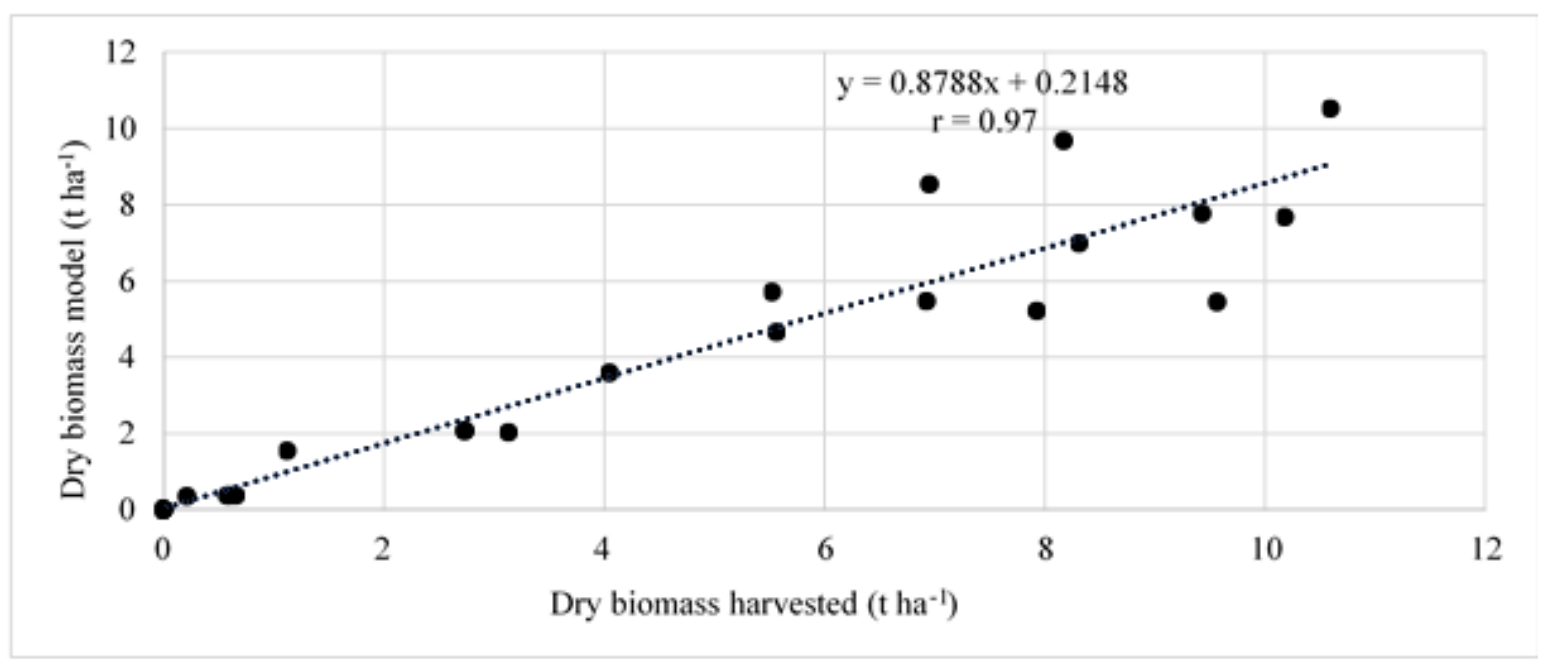




\section{CONCLUSION AND DISCUSSION}

\section{Meteorology and Irrigation}

Natural water supply did not satisfy the water needs of processing tomato in the 2018 season. Precise and site-specific meteorological data is needed when we want to determine irrigation water demand with AquaCrop computing potential evapotranspiration. The steps between the different water doses are 87,39 and $44 \mathrm{~mm}$, so it provides good resolution to examine the effect of water to the dry biomass yields.

\section{Biomass yields}

The modelled dry biomass yields followed well the measured samples in the C and I100 treatment through the whole season. By the time of the fourth sampling date, a big gap occurred between the modelled and the actual biomass yields in the I50 and I75 treatments, because the model underestimated until the final harvest date, but overestimated the final dry biomass yields. Overestimation of biomass by the model was observed by others as well in potato (Montoya et al., 2016). Seasonal evolution of biomass was simulated with a high degree of accuracy in maize and AquaCrop predicted final biomass adequately (Greaves and Wang, 2016). In addition, close relation was found between measured and simulated biomass yield of winter wheat, influenced by various planting dates and irrigation strategies (Jin et al., 2014). This phenomena caused the lower correlation in these two treatments. High level of overestiomation in the dry biomass of tomato under water stress was found by others (Katerji et al., 2013). By contrast, the $\mathrm{C}$ and I100 treatments showed very strong correlation with small miscalculations in the final dry biomass yields. The correlation for all of the data is also strong. The shape of the growth curves of the C and I100 treatments are very similar to each other and to the modelled curves too. On the other hand, the growth curves of the I50 and I75 treatments are different from the C and I100 curve's and the modelled curve's shape. This could happen because of the small sample size. Only four plants were taken as a sample at the $4^{\text {th }}$ and $5^{\text {th }}$ sampling date, where the model is greatly unprecise. The biomass reached the maximum in the I50 and 175 treatment to the $5^{\text {th }}$ sampling date, which is significantly higher than at the end of the season according to the measurements. Sample size can be an explanation for this as well. However, this cannot be an explanation for the miscalculation of the final dry biomass yields, when ten plants were taken as a sample. Therefore, the small sample size and the model's miscalculation together must be the reason for the modelling problems at the I50 and I75 treatments. As conclusion we state that modelling dry biomass yields for processing tomato with AquaCrop is very promising when we irrigate according to $100 \%$ of potential ET, computed by the model itself. Very good result was found in the $\mathrm{C}$ as well. Overestimation in general was found in the work of Katerji et al. (2013) in the case of corn and tomato biomass evaluation in the late stages of crop cycles, moreover, overestimation in evapotranspiration was found as well. Important to note, that punctual irrigation and field management must be used for model setting as well as climate data from reliable source, in order to achive more accuracy. Nevertheless, miscalculated modelled values as a result in the deficit irrigated treatments are not usable in this state. The strong correlation and the error values for all of the data is very promising. It can be used for rough estimations well on big scale. The most important task from a practical point of view is the dry yield modeling. Harvest index as a crop development indicator was evaluated by Linker et al. (2016) and they concuded that the model estimate more biomass to vegetation than to fruit in the early and mid growth stages. Fine-tuning of the model with the data gathered from deficit irrigation experiment of processing tomato will be a task for the future.

\section{ACKNOWLEDGEMENT}

The experiment for this study was supported by GINOP 2.2.1-15-2016-00003 project. The publication is supported by the EFOP-3.6.3-VEKOP-16-201700008 and the Higher Education Institutional Excellence Program (1783-3/2018/FEKUTSRAT) awarded by the Ministry of Human Capacities within the framework of water related researches of Szent István University project. The work of the authors was supported by EFOP-3.6.1-16-2016-00016 project.

\section{REFERENCES}

Allen, R. G.-Pereira, L. S.-Raes, D.-Smith, M.-Ab, W. (1998) Crop evapotranspiration - Guidelines for computing crop water requirements. FAO Irrigation and drainage paper 56. 1-15.

Bakr, J. A.-Daood, H. G.-Pék, Z.-Helyes, L.- Posta, K. (2017): Yield and Quality of Mycorrhized Processing Tomato Under Water Scarcity. Applied Ecology and Environmental Research. 15. 1: 401-413.

Bőcs, A.-Helyes, L.-Pék, Z. (2011): Simultaneous impact of the different water supply and year type on processing tomato yield. Intlernational Journal of Horticultural Science. 17.: 7981.
Food and Agriculture Organization (2018): Production quantities of Tomatoes by country.

García-Vila, M.-Fereres, E. (2012): Combining the simulation crop model AquaCrop with an economic model for the optimization of irrigation management at farm level. European Journal of Agronomy. 36. 1: 21-31.

Greaves, G. E.-Wang, Y. (2016): Assessment of FAO AquaCrop Model for Simulating Maize Growth and Productivity under Deficit Irrigation in a Tropical Environment.

Helyes, L.-Lugasi, A.-Daood, H. G.-Pék, Z. (2014): The simultaneous effect of water supply and genotype on yield 
quantity, antioxidants content and composition of processing tomatoes. Notulae Botanicae Horti Agrobotanici Cluj-Napoca. 42. 1: 143-149.

Helyes, L.-Lugasi, A.-Pék, Z. (2012): Effect of irrigation on processing tomato yield and antioxidant components. Turkish Journal of Agriculture and Forestry. 36. 6: 702-709.

Helyes, L.-Varga, G. (1994): Irrigation demand of tomato according to the results of three decades. Acta Horticulturae.

Hsiao, T. C.-Heng, L.-Steduto, P.-Rojas-Lara, B.-Raes, D.Fereres, E. (2009): Aquacrop-The FAO crop model to simulate yield response to water: III. Parameterization and testing for maize. Agronomy Journal. 101. 3: 448-459.

Jin, X. L.-Feng, H. K.-Zhu, X. K.-Li, Z. H.-Song, S. N.-Song, X. Y.-Yang, G.-Xu, X. G.- Guo, W. S. (2014): Assessment of the AquaCrop model for use in simulation of irrigated winter wheat canopy cover, biomass, and grain yield in the North China plain. PLoS ONE.

Katerji, N.-Campi, P.-Mastrorilli, M. (2013): Productivity, evapotranspiration, and water use efficiency of corn and tomato crops simulated by AquaCrop under contrasting water stress conditions in the Mediterranean region. Agricultural Water Management. 130.: 14-26.

Le, A. T.-Takács, S.-Bakr, J. A. (2016): Vízellátás és mikrobiológiai oltás együttes hatása a paradicsom mennyiségi és minőségi paramétereire. Kertgazdaság. 48. 4: 32-39.

Le, T. A.-Pék, Z.-Takács, S.-Neményi, A.-Daood, H. G.-Helyes, L. (2018): The Effect of Plant Growth Promoting Rhizobacteria on the Water-yield Relationship and Carotenoid Production of Processing Tomatoes Zolt a. HortScience. 53. 6: 816-822.

Linker, R.-Ioslovich, I.-Sylaios, G.-Plauborg, F.-Battilani, A. (2016): Optimal model-based deficit irrigation scheduling using AquaCrop: A simulation study with cotton, potato and tomato. Agricultural Water Management. 163.: 236-243.

Montoya, F.-Camargo, D.-Ortega, J. F.-Córcoles, J. I.-Domínguez, A. (2016): Evaluation of Aquacrop model for a potato crop under different irrigation conditions. Agricultural Water Management. 164.: 267-280.

Nemeskéri, E.-Molnár, K.-Pék, Z.-Helyes, L. (2018): Effect of water supply on the water use-related physiological traits and yield of snap beans in dry seasons. Irrigation Science. 36. 3: 143-158.

Nemeskéri, E.-Molnár, K.-Vígh, R.-Nagy, J.-Dobos, A. (2015): Relationships between stomatal behaviour, spectral traits and water use and productivity of green peas (Pisum sativum L.) in dry seasons. Acta Physiologiae Plantarum. 37. 2: 34.
Patané, C.-Cosentino, S. L. (2010): Effects of soil water deficit on yield and quality of processing tomato under a Mediterranean climate. Agricultural Water Management. 97. 1: 131-138.

Pék, Z.-Szuvandzsiev, P.-Neményi, A.-Helyes, L. (2015): Effect of season and irrigation on yield parameters and soluble solids content of processing cherry tomato. In Acta Horticulturae (Vol. 1081). 197-202.

R Core Team (2018): R: A language and environment for statistical computing. Vienna, Austria: R Foundation for Statistical Computing.

Raes, D. (2017): AquaCrop training handbooks Book I Understanding AquaCrop. Rome: Food and Agriculture Organization of the United Nations.

Raes, D.-van Gaelen, H. (2017): AquaCrop Training Handbook Book II. Rome: Food and Agriculture Organization of the United Nations

Steduto, P.-Hsiao, T. C.-Fereres, E.-Raes, D. (2012): Crop yield response to water. In Fao Irrigation and Drainage Paper. Rome: Food and Agriculture Organization of the United Nations.

Takács, S.-Bíró, T.-Helyes, L.-Pék, Z. (2018): Variable rate precision irrigation technology for deficit irrigation of processing tomato. Irrigation and Drainage. : in press.

Takács, S.-Máthé, B.-Katona, B. L.-Le, A. T.-Pék, Z. (2017): Ipari paradicsom modellezése AquaCrop szoftverrel. Kertgazdaság. 49. 4: 31-38.

Takács, S.-Molnár, T.-Csengeri, E.-Le, T. A. (2018): Application of AquaCrop in Processing Tomato Growing and Calculation of Irrigation Water. Acta Agraria Debreceniensis.

Todorovic, M.-Albrizio, R.-Zivotic, L.-Abi Saab, M. T.-Stöckle, C.-Steduto, P. (2009): Assessment of aquacrop, cropsyst, and WOFOST models in the simulation of sunfl ower growth under different water regimes. Agronomy Journal. 101. 3: 509-521.

Toumi, J.-Er-Raki, S.-Ezzahar, J.-Khabba, S.-Jarlan, L.Chehbouni, A. (2016): Performance assessment of AquaCrop model for estimating evapotranspiration, soil water content and grain yield of winter wheat in Tensift $\mathrm{Al}$ Haouz (Morocco): Application to irrigation management. Agricultural Water Management. 163.: 219-235.

Vanuytrecht, E.-Raes, D.-Steduto, P.-Hsiao, T. C.-Fereres, E.Heng, L. K.-Garcia Vila, M.-Mejias Moreno, P. (2014): AquaCrop: FAO's crop water productivity and yield response model. Environmental Modelling and Software. 62.: 351-360.

World Processing Tomato Council (2018): WPTC Crop update as of 31 August 2018. 